\title{
Survival Outcomes and Prognostic Factors in Salivary Gland Cancers Treated by Surgery and Adjuvant Radiotherapy
}

\author{
Cerrahi Sonrası Adjuvan Radyoterapi Gören Tükürük Bezi Tümörü Tanılı Hastalarda \\ Prognostik Faktörlerin Değerlendirilmesi ve Sağkalım Sonuçları
}

\author{
(D) Mürsel DÜZOVA ${ }^{1}$, (D) Tahir Sedat TURKAN² \\ 1Selçuk University Faculty of Medicine, Department of Radiation Oncology, Konya, Turkey \\ ${ }^{2}$ Kadıköy Florence Nightingale Hospital, Clinic of Radiation Oncology, Istanbul, Turkey
}

\begin{abstract}
Aim: To evaluate the variables affecting prognostic factors in patients with salivary gland cancer who have received surgery followed by radiotherapy (RT).

Materials and Methods: Fifty-three patients with major and minor salivary gland cancer were treated with curative surgery and postoperative RT between 1993 and 2011. We evaluated patients with regard to overall survival, locoregional recurrence-free survival, disease free survival, and distant metastasis-free survival.

Results: The median follow-up period was 40 (8-174) months. The rates of local control, distant metastasis-free, disease-free survival and overall survival after 10 years were $65 \%, 57,7 \%, 38,8 \%$, and 48,2\%, respectively. In univariate analysis, histological subtype, histologic grade, extraglandular extension and delivered dose of RT were found to be as prognostic factors affecting locoregional recurrence-free survival; gender, histological subtype, extraglandular extension influenced disease-free survival; overall survival was only affected by age. In multivariate analysis, locoregional recurrence-free survival was affected by histologic grade and dose of RT (60 Gy< better prognosis); distant metastasis-free survival was affected by histological subtype; disease-free survival was affected by histological subtype, histologic grade, and lymph node status; overall survival was affected by lymph node status, extraglandular extension, and dose of RT (60 Gy< better prognosis).

Conclusion: Several prognostic factors affecting local control, distant metastases, and overall survival were found. Postoperative RT is an effective treatment modality that increases local control and overall survival in patients with Salivary Gland Carcinoma at doses over $60 \mathrm{~Gy}$.
\end{abstract}

Keywords: Salivary gland cancer, radiotherapy, prognostic factor

\section{ÖZ}

Amaç: Postoperatif radyoterapi (RT) almış tükürük bezi tümörü tanılı hastalarda prognostik faktörleri etkileyen değişkenleri değerlendirmek amaçlandı.

Gereç ve Yöntem: 1993-2011 yılları arasında küratif cerrahi ve postoperatif RT ile tedavi edilen majör ve minör tükürük bezi kanserli elli üç hasta çalışmaya dahil edildi. Hastalar; genel sağkalım, lokorejyonel rekürrenssiz sağkalım, hastalıksız sağkalım ve uzak metastazsız sağkalım açısından değerlendirildi.

Bulgular: Medyan takip süresi 40 (8-174) aydı. On yıl sonra lokal kontrol, uzak metastazsız, hastalıksız sağkalım ve genel sağkalım oranları sırasıyla $\% 65, \% 57,7, \% 38,8$ ve \%48,2 idi. Tek değişkenli analizde, histolojik alt tip, histolojik grade, ekstraglandüler yayılım ve RT dozu lokorejyonel rekürrenssiz sağkalımı etkileyen prognostik faktörler olarak bulundu. Cinsiyet, histolojik alt tip, ekstraglandüler yayılım hastalıksız sağkalımı etkileyen

Address for Correspondence: Mürsel DÜZOVA MD, Selçuk University Faculty of Medicine, Department of Radiation Oncology, Konya, Turkey Phone: +90 5305677560 E-mail: mursel_duzova@hotmail.com ORCID ID: orcid.org/0000-0003-1036-2593

Received: 08.12.2020 Accepted: 09.02.2021

Presented in: This study was presented as an oral presentation at the $5^{\text {th }}$ International Hippocrates Congress of Medicine and Health Sciences, 18-19 December 2020, and its abstract text was included in the congress booklet. 
faktörler olarak bulunurken, genel sağkalım sadece yaştan etkilendi. Çok değişkenli analizde, lokorejyonel rekürrenssiz sağkalım histolojik grade ve RT dozundan (>60 Gy, daha iyi prognoz); uzak metastazsız sağkalım, histolojik alt tipten; hastalıksız sağkalım, histolojik alt tip, histolojik grade, lenf nodu durumundan; genel sağkalım, lenf nodu durumu, ekstraglandüler yayılma ve RT dozundan (>60 Gy, daha iyi prognoz) etkilenmiştir.

Sonuç: Lokal kontrolü, uzak metastaz gelişimini ve genel sağkalımı etkileyen çeşitli prognostik faktörler bulundu. Postoperatif RT, 60 Gy'nin üzerindeki dozlarda tükürük bezi karsinomu olan hastalarda lokal kontrolü ve genel sağkalımı artıran etkili bir tedavi yöntemidir.

Anahtar Kelimeler: Tükürük bezi kanseri, radyoterapi, prognostik faktör

\section{INTRODUCTION}

Salivary gland cancers (SGCs) are very rare cancer group. In the western countries 2.5-3 cases are diagnosed in approximately 100,000 per year. SGCs account for approximately $0.5 \%$ of all malignant tumors and 3-5\% of all head and neck cancers'. And also, it accounts for approximately $11 \%$ of oropharyngeal cancers ${ }^{2}$. Most SGCs are determined in $6-7^{\text {th }}$ decades ${ }^{3}$.

SGCs are diverse according to origin and pathology. They are classified according to the 2017 World Health Organization, which lists 20 subtypes of benign and 10 subtypes of malignant histopathologic types ${ }^{4}$. The most common histopathologic types are mucoepidermoid carcinoma (MEC), adenoid cystic carcinoma (ACC), adenocarcinoma not otherwise specified and salivary duct carcinoma. Generally, they are divided into two groups as those originating from the major and minor salivary glands. Parotid glands are the most common site of major SGCs, followed by submandibular glands and sublingual glands. Also, minor salivary glands are the source of SGCs, representing for $9-23 \%$ of all salivary gland tumors. The most common location of minor salivary glands is within the mucosa of the hard palate $^{5-7}$. However, parotid gland tumors are less likely to be malignant compared to other major and minor salivary gland tumors'.

Among the treatment options, surgical resection with adequate free margin is the most important option. Elective nodal treatment of the NO neck is still controversial. Postoperative radiotherapy (PORT) is an effective treatment modality in patients with high-risk factors such as high grade, poor prognosis histological subtype, advanced stage, etc. Little is known about chemotherapy in treatment strategy due to the small number of cases.

\section{MATERIALS AND METHODS}

\section{Ethical Approval}

The study was conducted in accordance with the ethical principles of the Declaration of Helsinki and approval from a local committee on human investigation was obtained. The study protocol was reviewed and approved by Clinical Research Ethics Committee, with decision date no of 06/11/2014-235913. Written informed consent forms were read by each patient and signed approvals were obtained before their treatment.

\section{Study Population}

Between the years of 1993 and 2011, a total of 211 cases with SGC of any prior treatment status and stage were identified in our databases. Due to the fact that SGCs are rare in the population, histopathological subtypes vary widely, and the treatment regimens are varied due to the lack of standard approaches in their treatment, an attempt was made to obtain a homogeneous group as much as possible to minimize confusion. Therefore, patients who did not have metastasis at the time of diagnosis, who had curative surgery with no macroscopic residue, who did not receive neoadjuvant, adjuvant or concurrent chemotherapy, and who received definitive dose of RT postoperatively were selected and included in the study. Fifty-three of these 211 cases suited with inclusion criteria and they were retrospectively reviewed.

\section{Inclusion and Exclusion Criteria}

\section{Inclusion criteria:}

- Patients who were diagnosed with major or minor SGC,

- Patients who underwent surgery,

- Patients who received PORT,

- Patients without macroscopic residual mass after surgery,

- Patients who did not receive neoadjuvant, adjuvant or concurrent chemotherapy.

\section{Exclusion criteria:}

- Patients with relapse before RT,

- Patients who did not undergo surgery before RT,

- Patients who had a history of malignant disease priorly,

- Patients who developed second primer malignancy during follow-up,

- Patients who had metastasis before RT,

- Patients with macroscopic residual mass after surgery (R2 resection),

- Patients with immunosuppressive disease. 


\section{Statistical Analysis}

Study data were analyzed using the statistical package program Statistical Package for the Social Sciences version 13.0. As descriptive statistics, numerics, percentage, standard deviation, average, and minimum and maximum values were used. Locoregional recurrence-free survival (LRFS), disease free survival (DFS), distant metastasis-free survival (DMFS), and overall survival (OS) were estimated using the Kaplan-Meier method (Graphic 1, 2). To identify prognostic factors that might influence survival, log rank tests were performed to examine the univariate associations between survival and parameters of interest and Cox regression analysis was performed to

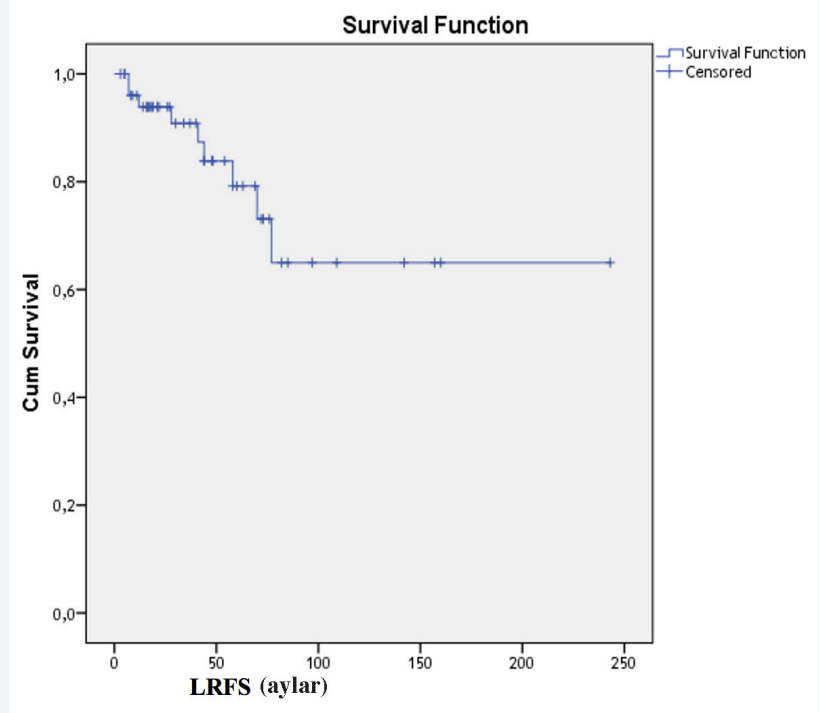

Graphic 1. Locoregional recurrence-free survival

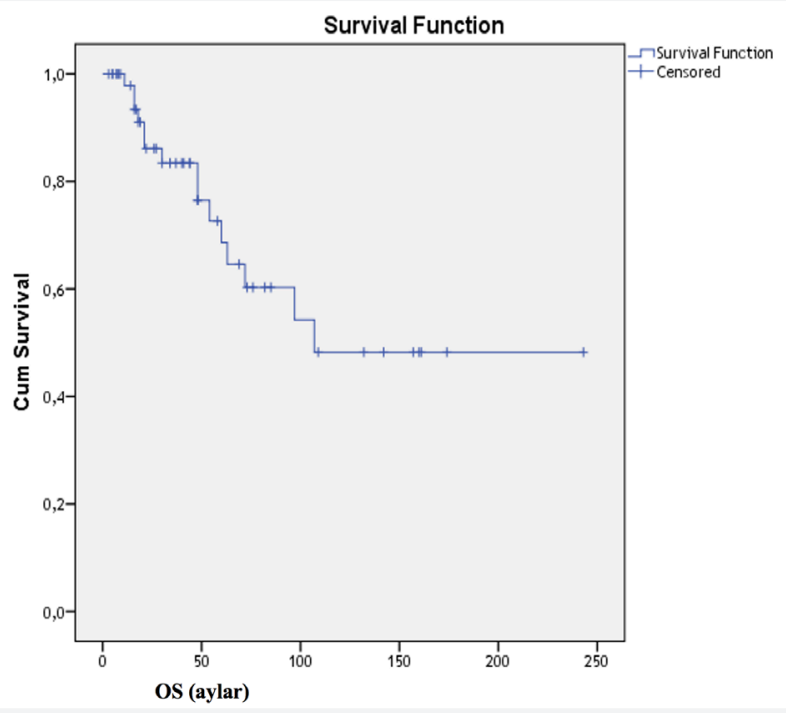

Graphic 2. Overall survival examine the multivariate associations. The value of $p<0.05$ was considered statistically significant.

\section{RESULTS}

\section{Patient Characteristics}

Of 53 patients, $40(75.5 \%)$ had parotid, 6 (11.3\%) had submandibular, 7 (13.2\%) had minor salivary gland located tumors. Facial paralysis was presented in $16(30.2 \%)$ patients with parotid gland tumors at the time of first presentation. The median age was 52 years (range 16-83 years). Twentyeight $(52.8 \%)$ patients were male and $25(47.2 \%)$ were female. Histopathological distribution was like this; 13 (24.5\%) patients had ACC, 10 (18.9\%) patients had MEC, 9 (17\%) patients had squamous cell carcinoma (SCC), 7 (13.2\%) patients had adenocarcinoma, $5(9 \%$, 4) patients had acinic cell carcinoma, $3(5.6 \%)$ patients had malignant mixed tumor, 2 (3.7\%) patients had carcinoma ex pleomorphic adenoma, 1 $(1.8 \%)$ patient had clear cell carcinoma, $1(1.8 \%)$ patient had lymphoepithelioma, $1(1.8 \%)$ patient had malignant eccrine poroma, $1(1.8 \%)$ patient had malignant lymphoepithelial lesion, respectively (Table 1).

\section{Treatment Outcome and Survival}

We analyzed general results and investigated the potential prognostic variables of age, gender, tumor size and lymph node status, anatomic site, facial weakness, histological types, histological grade, extraglandular extension, resection margins, perineural invasion, and radiotherapy (RT) dose. The date of diagnosis was accepted as the date of histological diagnosis of SGC. The last follow-up date was the date of the last consultation. All tumors were classified by tumor $(\mathrm{T})$, lymph node $(\mathrm{N})$, and metastasis staging system, seventh edition (International Union Against Cancer, 2009). All patients underwent surgery. In forty of 53 patients, tumors were located in the parotid gland. Among 40 patients with parotid gland tumors, total parotidectomy was performed for 14 (26.4\%), partial parotidectomy for $3(5.6 \%)$, superficial parotidectomy for $3(5.6 \%)$, total parotidectomy with neck dissection for 19 $(35.8 \%)$, and superficial parotidectomy with neck dissection for $1(1.8 \%)$ patient. In cases of submandibular gland tumors, wide excision was performed for $4(7.5 \%)$ patients and wide excision with neck dissection was performed for 2 (3.7\%) patients. In cases of minor salivary gland tumors, mass excision was performed for $5(9.4 \%)$ patients, mass excision with neck dissection was performed for $1(1.8 \%)$ patient. Totally, neck dissection was performed for $24(45.2 \%)$ patients. Fourteen $(26.4 \%)$ of the cases were with node involvement.

Only patients who received definitive PORT were included in the study. RT indication was decided according to whether the patients were at high risk or not. Patients having T stage 
T3-T4 tumor, and/or lymph node positivity, and/or perineural or lymphovascular invasion, and/or positive surgical margins, and/or high-grade tumor were considered high-risk patients, and those who had one or more of these features were treated with PORT. RT period was median 42 days (range 33-61). In 35 (66\%) patients, RT was performed only to the postoperative tumor bed. In 18 patients, neck region was also included in RT treatment site. The median 50 Gy (46-66 Gy) was delivered to neck region and $60 \mathrm{~Gy}(50-70 \mathrm{~Gy})$ to postoperative tumor bed.

None of the patients received concurrent, adjuvant or neoadjuvant chemotherapy. The median follow-up was 40 months (range 8-174). Patients were followed up after 4-6 weeks following the completion of treatment and then every 3 months for 2 years. The patients were then followed up every 6 months. Physical examination and head and neck/thorax computed tomography scan was performed during follow-up visit when necessary.

The 5-year and 10-year LRFS, DMFS, and DFS rates were 79.2\% and $65 \%, 77 \%$ and $57.7 \%, 61.6 \%$ and $38.8 \%$, respectively.

\begin{tabular}{|c|c|}
\hline Parameter & Number of patients (\%) \\
\hline \multicolumn{2}{|l|}{ Age } \\
\hline $60 y>$ & $31(58.5)$ \\
\hline $60 y \leq$ & $22(41.5)$ \\
\hline \multicolumn{2}{|l|}{ Gender } \\
\hline Male & $28(52.8)$ \\
\hline Female & 25 (47.2) \\
\hline Facial paralysis & $16(32.2)$ \\
\hline \multicolumn{2}{|l|}{ Location } \\
\hline Parotid gland & $40(75.5)$ \\
\hline Submandibular gland & $6(11.3)$ \\
\hline Minor salivary gland & $7(13.2)$ \\
\hline \multicolumn{2}{|l|}{ Histological subtype } \\
\hline Adenoid cystic $\mathrm{Ca}$ & $13(24.5)$ \\
\hline Mucoepidermoid Ca & $10(18.9)$ \\
\hline Squamous cell Ca & $9(17)$ \\
\hline Adeno Ca & 7 (13.2) \\
\hline Acinic cell Ca & $5(9.4)$ \\
\hline Other subtypes & $9(17)$ \\
\hline \multicolumn{2}{|l|}{ Tumor diameter } \\
\hline $4 \mathrm{~cm}>$ & $27(51)$ \\
\hline $4 \mathrm{~cm} \leq$ & $26(49)$ \\
\hline Lymph node involvement & $14(26.4)$ \\
\hline Extraglandular extension & $10(18.9)$ \\
\hline \multicolumn{2}{|l|}{ Dose of RT } \\
\hline $60 \mathrm{~Gy}$ & $32(60.4)$ \\
\hline $60 \mathrm{~Gy}>$ & $14(26.4)$ \\
\hline $60 \mathrm{~Gy}<$ & 7 (13.2) \\
\hline
\end{tabular}

The 5-year and 10-year OS rates were $68.6 \%$ and $48.2 \%$, respectively. Twenty patients (37.7\%) had recurrence (only locoregional failures in 7, only distant failures in 11, and both locoregional and distant failures in 2 patients). The sites of distant metastases included the lungs $(n=9)$, bone $(n=3)$ and brain $(n=1)$. Of nine patients who developed locoregional recurrence, 4 had MEC, 2 had ACC, 2 had adenocarcinoma, and 1 had SCC histological subtype.

\section{Prognostic Factors}

Univariate analysis revealed that extraglandular extension $(p<0.007)$, dose of RT $(p<0.006)$, histological subtype $(p<0.019)$ and histological grade $(p<0.005)$ were significant prognostic factors on LRFS. And also, histological grade $(p<0.038)$ and dose of $R T(p<0.019)$ were significant prognostic factors on LRFS in multivariate analysis (Table 2,3 ).

The factors that affecting OS were age (60 $y \leq$, poor prognosis) $(p<0.014)$ in univariate analysis and extraglandular extension $(p<0.033)$, dose of RT $(p<0,04)$, and lymph node involvement $(p<0.024)$ in multivariate analysis. In addition, histological

Table 2. Significant prognostic factors in univariate analysis

\begin{tabular}{|l|l|l|}
\hline \multirow{4}{*}{$\begin{array}{l}\text { Lverall survival } \\
\text { recurrenional } \\
\text { survival }\end{array}$} & $\begin{array}{l}\text { Age }(\mathbf{6 0} \mathbf{y} \leq \text {, poor prognosis) } \\
\text { prognosis) }\end{array}$ & $\mathbf{p}<\mathbf{0 . 0 1 4}$ \\
\cline { 2 - 3 } & Histological grade & $\mathrm{p}<0.019$ \\
\cline { 2 - 3 } & Extraglandular extension & $\mathrm{p}<0.005$ \\
\cline { 2 - 3 } & Dose of RT (60 Gy<, better prognosis) & $\mathrm{p}<0.006$ \\
\hline \multirow{2}{*}{$\begin{array}{l}\text { Distant } \\
\text { metastasis-free } \\
\text { survival }\end{array}$} & No & $\mathrm{No}$ \\
\hline \multirow{2}{*}{$\begin{array}{l}\text { Disease-free } \\
\text { survival }\end{array}$} & Gender (male, worse) & $\mathrm{p}<0.037$ \\
\cline { 2 - 3 } & Histological subtype (MEC, worse) & $\mathrm{p}<0.032$ \\
\cline { 2 - 3 } & Extraglandular extension & $\mathrm{p}<0.004$ \\
\hline MEC: Mucoepidermoid carcinoma & \\
\hline
\end{tabular}

Table 3. Significant prognostic factors in multivariate analysis

\begin{tabular}{|l|l|l|}
\hline \multirow{4}{*}{ Overall survival } & Lymph node status & $\mathrm{p}<0.024$ \\
\cline { 2 - 3 } & Extraglandular extension & $\mathrm{p}<0.033$ \\
\cline { 2 - 3 } & $\begin{array}{l}\text { Dose of RT (60 Gy<, better } \\
\text { prognosis) }\end{array}$ & $\mathrm{p}<0.040$ \\
\hline \multirow{2}{*}{$\begin{array}{l}\text { Locoregional recurrence- } \\
\text { free survival }\end{array}$} & Histological grade & $\mathrm{p}<0.038$ \\
\cline { 2 - 3 } & $\begin{array}{l}\text { Dose of RT (60 Gy<, better } \\
\text { prognosis) }\end{array}$ & $\mathrm{p}<0.019$ \\
\hline $\begin{array}{l}\text { Distant metastasis-free } \\
\text { survival }\end{array}$ & $\begin{array}{l}\text { Histological subtype (MEC, } \\
\text { poor prognosis) }\end{array}$ & $\mathrm{p}<0.028$ \\
\hline \multirow{2}{*}{ Disease-free survival } & $\begin{array}{l}\text { Histological subtype (MEC, } \\
\text { poor prognosis) }\end{array}$ & $\mathrm{p}<0.031$ \\
\cline { 2 - 3 } & Histological grade & $\mathrm{p}<0.015$ \\
\cline { 2 - 3 } & Lymph node status & $\mathrm{p}<0.013$ \\
\hline \multirow{2}{*}{ MEC: Mucoepidermoid carcinoma } & \\
\hline
\end{tabular}


grade $(\mathrm{p}<0.057)$ showed a trend to be significant in multivariate analysis (Table 2,3 ).

Histological subtype was the only factor affecting DMFS in multivariate analysis $(p<0.028)$. The factors affecting DFS were gender $(p<0.037$, male poor prognosis), histological subtype $(p<0.032)$, and extraglandular extension $(p<0.004)$ in univariate analysis; histological subtype $(p<0.031)$, histological grade $(p<0.015)$, and lymph node involvement $(p<0.013)$ were found statistically significant in multivariate analysis (Table 2,3 ).

\section{DISCUSSION}

In the past, surgery was the primary treatment for SGCs, and the concept of PORT was controversial. The reason for this was the lack of studies comparing only surgery and surgery with PORT. Although there is currently no randomized study on this subject, it has been shown that local control has increased with the addition of RT to surgery as a result of many retrospective studies in recent year ${ }^{8-12}$. Still today, there are no published prospective studies evaluating prognostic factors in SGCs. There are several studies that show multivariate analysis results with a large number of patients diagnosed with major and minor SGCs ${ }^{10-15}$. Studies on SGCs were mostly performed by evaluating major salivary glands ${ }^{916,17}$, minor salivary glands ${ }^{18-21}$ or more often, parotid gland tumors $10,11,22-26$.

In this study, various factors affecting LRFS, DFS, OS, and DMFS were evaluated in patients diagnosed with major and minor SGCs, who only received surgery followed by PORT.

Distant metastasis was detected in 13 (24.5\%) patients. This rate is between $15 \%$ and $37 \%$ in some studies $14,16,27-29$. In the analyzed group of patients, distant metastasis development rate was found to be compatible with that in articles. As in the study of Renehan et al. ${ }^{14}$, similarly, most of metastases occurred in the lung with $9(69 \%)$ patients, $3(23 \%)$ in the bone, and $1(8 \%)$ in the brain.

In recent study, 10 -year DFS rate was $38.8 \%$. Similarly, this rate ranges between $37 \%$ and $69 \%$ in various studies ${ }^{5,14,16,29,30}$. Thus, the DFS rate, in our study, was found to be compatible with the literature.

In the current study, 9 (16.9\%) patients developed local recurrence. This rate was found similar to the studies of Fitzpatrick and Theriault ${ }^{29}$ and Borthne et al. ${ }^{30}$. However, higher rates have also been reported in some studies. In the study of Fu et al. ${ }^{28}$, which included 100 patients with SGCs, the 5 -year recurrence rate was $28 \%$. In a historically important study published by Spiro ${ }^{27}$ in 1986, the rate of locoregional recurrence was found to be as high as 39\% in the parotid gland, and $60 \%$ in the submandibular gland and minor salivary gland tumors. However, in this study, most patients received only surgical treatment. Nevertheless, in another study published by Spiro et al. ${ }^{16}$, lower recurrence rates were reported (local recurrence rate was $21 \%$, and regional recurrence rate was $10 \%$ ). The difference of this study from the previous study was that more patients received RT postoperatively. Similar results were also found in the study of Armstrong et al. ${ }^{12}$ which showed that while the locoregional control rate was $69 \%$ in the arm of PORT, it was lower (40\%) in the arm of only surgery. However, in our study, the 5-year locoregional control rate was $79.2 \%$, which was slightly higher than in many studies. May be, the reason of this is that all selected patients in the recent study received both treatment modalities, surgery and PORT.

In the current study, the location of most tumors was in the parotid gland at a rate of 75.5\% (40 patients), as mentioned in the literature, and $7(13.2 \%)$ patients' diseases were in the minor salivary glands and $6(11.3 \%)$ in the submandibular glands, respectively. Also, in a Swedish epidemiological study ${ }^{31}$, which included 3305 patients, similar rates were detected (58\% in parotid, $11 \%$ in submandibular, $23 \%$ in minor salivary gland location). In the analyzed group of patients, 3 of 7 patients diagnosed with minor SGCs were located in the maxilla, 1 in the nasal cavity, 1 in the tonsil, 1 in the hard palate, 1 in the mouth floor. These findings were incompatible with some studies in the literature. Conversely, in some studies ${ }^{18,27}$, the most common location of minor SGCs appeared in the palate.

In our cohort, lymph node involvement was detected in 14 (26.4\%) patients. Thirteen of these 14 patients' tumor sites were in the parotid gland and 1 in minor salivary gland. None of the patients with lymph node involvement was detected in submandibular gland. However, in various studies, lymph node involvement rate in the submandibular gland tumor was reported to be between $19 \%$ and $25 \% 0^{32,33}$. In the present study, the rate of developing metastasis to the lymph node in patients with tumors located in the parotid gland was $32.5 \%$, which was similar or close to many studies' results in some published articles ${ }^{10-12,22,26}$.

In the current study, the location of tumor was not found as a prognostic factor affecting LRFS, OS, DFS, and DMFS in either univariate analysis or multivariate analysis. While these results are similar to those in some studies in the literature ${ }^{29}$, opposite results have also been reported in some other studies ${ }^{15,34}$. In the study of Vander Poorten et al. ${ }^{22}$, it was found that histological grade in parotid gland tumors had no effect on DFS. However, in this study, grade was divided into two categories as high grade and low grade; moreover, MEC and acinic cell carcinoma were classified as low grade. These results differed from the results of the studies of Kane et al. ${ }^{25}$ and Frankenthaler et al. ${ }^{11}$. In these two studies, ACC was included in the low-grade group and high-grade tumors associated with decreased survival. In the analyzed group of patients, 
histological grade was related to LRFS in univariate analysis $(p<0.005)$ and close to significance $(p<0.06)$ on DFS, and in multivariate analysis, it was related to LRFS $(p<0.038)$ and DFS $(p<0.015)$, and close to significance on OS $(p<0.057)$.

In the present study, most common histological subtype was ACC in $13(24.5 \%)$ patients. In these 13 patients, the tumor location was in the submandibular gland in 5 , in the minor salivary gland in 5 and in the parotid gland in 3 . These rates were similar to the rates of other studies ${ }^{31,32,34}$. In our cohort, the lymph node involvement rate of the patients with ACC was $7.6 \%$, which is similar to some other publications ${ }^{10,33}$. In the current study, the rate of perineural invasion was found to be $33.9 \%$, similar to a very large patient-numbered study by Westergaard-Nielsen et al. ${ }^{5}$. While ACC histology may remarkably show local recurrence by neural invasion, in our study, ACC histology was not found to be a factor reducing local control as in the study of Terhaard et al. ${ }^{34}$ This may be due to the combined treatment modality being used. As in a large patient-numbered study ${ }^{35}$, acinic cell carcinomas were more frequently observed in the parotid gland (in our study, all 5 acinic cell carcinomas were noticed in the parotid gland). In the study of Hoffman et al. ${ }^{35}$ including 1353 cases, lymph node involvement was found around $10 \%$ in tumors with acinic cell histology and distant metastasis rates ranged from 3\% to 17\% in various studies 34,35 . In the analyzed group of patients, no lymph node or distant metastases were detected in any of the 5 patients with acinic cell histology.

In the current study, 10 (18.9\%) patients had MEC histology. All of them originated from the parotid gland and it constituted $25 \%$ of parotid gland tumors. This rate had a wide range of $10 \%$ to $38 \%$ in various studies ${ }^{10,11,16,22,23,25,30,31}$. In our study, lymph node involvement was present in 50\% of patients diagnosed with MEC. This result was slightly higher than the rates (14-45\%) in the literature ${ }^{12,33,36,37}$. Additionally, distant metastasis developed in 30\% of patients in the recent study. This rate was lower (16\%) in the study of Terhaard et al. ${ }^{34}$. Over and above this, in the current study, MEC histology was found to be associated with distant metastasis development and DFS in multivariate analysis.

All $9(17 \%)$ cases with SCC histology were observed in the parotid gland. In general, these tumors were observed in older men. In the patients with SCC histology, lymph node involvement was around $22 \%$ in the present study. In the study of Terhaard et al. ${ }^{34}$, a higher rate of 30\% was found. Because of the high lymph node metastasis rate of SCC histology, the authors generally recommend elective neck treatment. In addition, distant metastasis rate was found as low as $11 \%$. In the study of Terhaard et al. ${ }^{37}$, the 10-year distant metastasis rate was found to be $35 \%$.
In the analyzed group of patients, histological subtype was found to be one of the factors affecting LRFS and DFS in univariate analysis. In multivariate analysis, it was found that MEC histology was associated with distant metastasis development and DFS. Apart from the study of Therkildsen et al. ${ }^{15}$, in many publications, histological subtype was not found as an independent factor affecting either locoregional control ${ }^{13,26}$ or distant metastasis development ${ }^{11}$. While some studies ${ }^{9} 10,14,16,19,20$ have found histological subtype prognostically important, on the contrary, in some studies ${ }^{11,13,22,25,26}$, it is prognostically not important.

In the present study, while age was the only factor affecting OS in univariate analysis, it was not a prognostic factor in multivariate analysis. Although the male and female ratios were almost close to each other, women generally seemed to get diagnosed with SGC at younger ages and more likely to have histologies of ACC, adenocarcinoma, and acinic cell carcinoma. While gender was found as a prognostic factor affecting DFS in univariate analysis, no significance was found in multivariate analysis. In the study of Terhaard et al. ${ }^{34}$, gender was found to be an independent factor for distant metastasis development. In some studies ${ }^{25}$, male gender was associated with low OS rate.

According to the results of some studies, facial nerve dysfunction in parotid tumors is a prognostic factor affecting LRFS $^{26}$ and DFS $11,22,26$. However, in our study, it was not found as a factor affecting prognosis.

In the current study, when creating patient groups, we evaluated the tumor diameter by $4 \mathrm{~cm}$ and above and below $4 \mathrm{~cm}$, and evaluated the lymph node status as positive or negative. In univariate analysis, we could not find significance in both parameters. In multivariate analysis, we found lymph node status as a statistically significant factor on OS and DFS. According to most studies in the literature, nodal stage is an independent factor associated with DFS $10,11,19,22,25,26$. In the study of Terhaard et al. ${ }^{34} \mathrm{~T}$ and $\mathrm{N}$ stages were found to be independent prognostic factors for the development of distant metastasis. At the same time, they found a relationship between local control and T stage, and regional control and $\mathrm{N}$ stage.

Although surgical margin is found to be as an independent factor affecting prognosis in some studies ${ }^{15,23,34}$, in this limitednumbered cohort, it was not found to be as a factor affecting prognosis neither in univariate analysis nor in multivariate analysis.

Extraglandular extension was found to be a prognostic factor affecting LRFS and DFS in univariate analysis, and OS in multivariate analysis, as one of the remarkable results. In some studies, extraglandular extension was found to be an independent prognostic factor affecting local recurrence 
development ${ }^{34}$ and $\mathrm{OS}^{23,34}$. While no prognostic effect of perineural invasion was demonstrated in recent study, in the study of Terhaard et al. ${ }^{34}$, perineural invasion was found to be an independent prognostic factor that increased the risk of distant metastases by 2.2 times.

All patients included in our study were selected only from patients who received PORT. Since all patients underwent only PORT, they were not compared to any other treatment modality. RT generally increased both local control and OS in retrospective series with large numbers of patients, comparing only surgical and PORT treatment modalities ${ }^{8,11,12}$.

In head and neck cancers, the time interval between surgery and RT is important for locoregional control. This does not seem to be very valid for salivary gland tumors ${ }^{36}$. In the study group, the period from surgery to RT onset was median 57 days (range 25-155), and it was not detected as a prognostic factor.

In most studies, no significant correlation was found between received dose of RT and prognosis. However, in our analyzed group, dose of RT was found to be an independent prognostic factor affecting LRFS $(p<0.019)$ and OS $(p<0.040)$. Particularly, this effect became evident at doses over $60 \mathrm{~Gy}$. Many factors are taken into account when choosing dose of RT to be delivered. Particularly, resection margin status is a very critical issue that is taken into account when deciding on delivered dose of $\mathrm{RT}^{37}$. In the study of Garden et al. ${ }^{26}$, a trend towards higher local control was observed at doses of $60 \mathrm{~Gy}$ and above. Some authors recommend applying a radiation dose of 65 Gy and over for high-risk (incomplete resection) patients and $70 \mathrm{~Gy}$ RT for gross residual disease ${ }^{37}$.

\section{Study Limitations}

Due to the rarity of SGCs in the population, a small number of samples were included in the study. The study was conducted in a single center, and it was a retrospective study. These situations are the main limitations of the study.

\section{CONCLUSION}

PORT increases both local control and OS with higher doses of delivered RT (60 Gy $\leq$ ). Additionally, histological subtype, histological grade, lymph node involvement and extraglandular extension were determined as independent factors affecting prognosis. Institutions dealing with health sciences should collaborate to design prospective randomized studies on diseases with low frequency in the population. Multi-institutional randomized clinical trials are needed in this regard.

\section{Ethics}

Ethics Committee Approval: The study protocol was reviewed and approved by İstanbul University Cerrahpaşa-Cerrahpaşa
Faculty of Medicine Clinical Research Ethics Committee, with decision date no of 06/11/2014-235913.

Informed Consent: Written informed consent forms were read by each patient and signed approvals were obtained before their treatment.

Peer-review: Externally peer-reviewed.

\section{Authorship Contributions}

Surgical and Medical Practices: M.D., Concept: T.S.T., Design: T.S.T., Data Collection or Processing: M.D., Analysis or Interpretation: M.D., Literature Search: M.D., Writing: M.D., T.S.T.

Conflict of Interest: No conflict of interest was declared by the authors.

Financial Disclosure: The authors declared that this study received no financial support.

\section{References}

1. Speight PM, Barrett AW. Salivary gland tumours. Oral Dis. 2002;8:229-40.

2. Ries LAG, Harkins D, Krapcho M, Mariotto A, Miller BA, Feuer EJ, et al. SEER Cancer Statistics Review, 1975-2003. Available from: https://seer.cancer. gov/archive/csr/1975_2003/

3. Wahlberg P, Anderson H, Biörklund A, Möller T, Perfekt R. Carcinoma of the parotid and submandibular glands--a study of survival in 2465 patients. Oral Oncol. 2002;38:706-13.

4. Seethala RR, Stenman G. Update from the 4th Edition of the World Health Organization Classification of Head and Neck Tumours: Tumors of the Salivary Gland. Head Neck Pathol. 2017;11:55-67.

5. Westergaard-Nielsen M, Godballe C, Eriksen JG, Larsen SR, Kiss K, Agander T, et al. Salivary gland carcinoma in Denmark: a national update and followup on incidence, histology, and outcome. Eur Arch Otorhinolaryngol. 2021:278:1179-88

6. Kordzińska-Cisek I, Grzybowska-Szatkowska L.Salivary gland cancerepidemiology. Nowotwory. Journal of Oncology. 2018;68:22-7.

7. Ito FA, Ito K, Vargas PA, de Almeida OP, Lopes MA. Salivary gland tumors in a Brazilian population: a retrospective study of 496 cases. Int J Ora Maxillofac Surg. 2005;34:533-6.

8. Spiro IJ, Wang CC, Montgomery WW. Carcinoma of the parotid gland Analysis of treatment results and patterns of failure after combined surgery and radiation therapy. Cancer. 1993;71:2699-705.

9. Cheraghlou S, Kuo P, Mehra S, Agogo G0, Bhatia A, Husain ZA, et al. Adjuvant therapy in major salivary gland cancers: Analysis of 8580 patients in the National Cancer Database. Head Neck. 2018;40:1343-55.

10. Parikh AS, Khawaja A, Puram SV, Srikanth P, Tjoa T, Lee H, et al. Outcomes and prognostic factors in parotid gland malignancies: A 10-year single center experience. Laryngoscope Investig Otolaryngol. 2019;4:632-9.

11. Frankenthaler RA, Luna MA, Lee SS, Ang KK, Byers RM, Guillamondegui $\mathrm{OM}$, Wolf $\mathrm{P}$, Goepfert H. Prognostic variables in parotid gland cancer. Arch Otolaryngol Head Neck Surg. 1991;117:1251-6.

12. Armstrong JG, Harrison LB, Spiro RH, Fass DE, Strong EW, Fuks ZY Malignant tumors of major salivary gland origin. A matched-pair analysis of the role of combined surgery and postoperative radiotherapy. Arch Otolaryngol Head Neck Surg. 1990;116:290-3.

13. Jones AS, Beasley NJ, Houghton DJ, Helliwell TR, Husband DJ. Tumours of the minor salivary glands. Clin Otolaryngol Allied Sci. 1998;23:27-33. 
14. Renehan A, Gleave EN, Hancock BD, Smith P, McGurk M. Long-term follow-up of over 1000 patients with salivary gland tumours treated in a single centre. Br J Surg. 1996;83:1750-4.

15. Therkildsen $M H$, Christensen $M$, Andersen $\amalg$, Schiødt T, Hansen HS. Salivary gland carcinomas--prognostic factors. Acta Oncol. 1998;37:701-13.

16. Spiro RH, Armstrong J, Harrison L, Geller NL, Lin SY, Strong EW. Carcinoma of major salivary glands. Recent trends. Arch Otolaryngol Head Neck Surg. 1989;115:316-21.

17. Lombardi $D$, Tomasoni $M$, Paderno A, Mattavelli D, Ferrari M, Battocchio $S$, et al. The impact of nodal status in major salivary gland carcinoma: A multicenter experience and proposal of a novel $\mathrm{N}$-classification. Oral Oncol. 2021;112:105076.

18. Goel AN, Badran KW, Braun APG, Garrett AM, Long JL. Minor Salivary Gland Carcinoma of the Oropharynx: A Population-Based Analysis of 1426 Patients. Otolaryngol Head Neck Surg. 2018;158:287-94.

19. Hay AJ, Migliacci J, Karassawa Zanoni D, McGill M, Patel S, et al. Minor salivary gland tumors of the head and neck-Memorial Sloan Kettering experience: Incidence and outcomes by site and histological type. Cancer. 2019;125:3354-66.

20. Baddour HM Jr, Fedewa SA, Chen AY. Five- and 10-Year Cause-Specific Survival Rates in Carcinoma of the Minor Salivary Gland. JAMA Otolaryngol Head Neck Surg. 2016;142:67-73.

21. He S, Li P, Zhong Q, Hou L, Yu Z, Huang Z, et al. Clinicopathologic and prognostic factors in adenoid cystic carcinoma of head and neck minor salivary glands: A clinical analysis of 130 cases. Am J Otolaryngol. 2017;38:157-62.

22. Vander Poorten VL, Balm AJ, Hilgers FJ, Tan IB, Loftus-Coll BM, Keus RB, et al. The development of a prognostic score for patients with parotid carcinoma. Cancer. 1999;85:2057-67.

23. Honda $\mathrm{K}$, Tanaka $\mathrm{S}$, Shinohara $\mathrm{S}$, Asato $\mathrm{R}$, Tamaki $\mathrm{H}$, Maetani $\mathrm{T}$, et al. Survival in patients with parotid gland carcinoma - Results of a multicenter study. Am J Otolaryngol. 2018;39:65-70.

24. Nakano T, Yasumatsu R, Kogo R, Hashimoto K, Asai K, Ohga S, et al. Parotid gland carcinoma: 32 years' experience from a single institute. J Laryngol Otol. 2019;133:604-9.

25. Kane WJ, McCaffrey TV, Olsen KD, Lewis JE. Primary parotid malignancies. A clinical and pathologic review. Arch Otolaryngol Head Neck Surg. 1991;117:307-15.
26. Garden AS, el-Naggar AK, Morrison WH, Callender DL, Ang KK, Peters $\sqcup$. Postoperative radiotherapy for malignant tumors of the parotid gland. Int J Radiat Oncol Biol Phys. 1997;37:79-85.

27. Spiro RH. Salivary neoplasms: overview of a 35-year experience with 2,807 patients. Head Neck Surg. 1986;8:177-84.

28. Fu KK, Leibel SA, Levine ML, Friedlander LM, Boles R, Phillips TL. Carcinoma of the major and minor salivary glands: analysis of treatment results and sites and causes of failures. Cancer. 1977;40:2882-90.

29. Fitzpatrick PJ, Theriault C. Malignant salivary gland tumors. Int J Radiat Oncol Biol Phys. 1986;12:1743-7.

30. Borthne A, Kjellevold K, Kaalhus O, Vermund H. Salivary gland malignant neoplasms: treatment and prognosis. Int J Radiat Oncol Biol Phys. 1986;12:747-754.

31. Ostman J, Anneroth G, Gustafsson H, Tavelin B. Malignant salivary gland tumours in Sweden 1960-1989--an epidemiological study. Oral Oncol. 1997;33:169-76.

32. Weber RS, Byers RM, Petit B, Wolf $P$, Ang K, Luna M. Submandibular gland tumors. Adverse histologic factors and therapeutic implications. Arch Otolaryngol Head Neck Surg. 1990;116:1055-60.

33. McGuirt WF. Management of occult metastatic disease from salivary gland neoplasms. Arch Otolaryngol Head Neck Surg. 1989;115:322-5.

34. Terhaard $\mathrm{CH}$, Lubsen $\mathrm{H}$, Van der Tweel I, Hilgers FJ, Eijkenboom WM, Marres $\mathrm{HA}$, et al. Salivary gland carcinoma: independent prognostic factors for locoregional control, distant metastases, and overall survival: results of the Dutch head and neck oncology cooperative group. Head Neck. 2004;26:681-92.

35. Hoffman HT, Karnell LH, Robinson RA, Pinkston JA, Menck HR. National Cancer Data Base report on cancer of the head and neck: acinic cell carcinoma. Head Neck. 1999;21:297-309.

36. Brandwein MS, Ivanov $\mathrm{K}$, Wallace DI, Hille JJ, Wang B, Fahmy $\mathrm{A}$, et al. Mucoepidermoid carcinoma: a clinicopathologic study of 80 patients with special reference to histological grading. Am J Surg Pathol. 2001;25:83545.

37. Terhaard CH, Lubsen $\mathrm{H}$, Rasch CR, Levendag PC, Kaanders HH, Tjho-Heslinga $\mathrm{RE}$, et al. The role of radiotherapy in the treatment of malignant salivary gland tumors. Int J Radiat Oncol Biol Phys. 2005;61:103-11. 